\title{
Developing Interactive Computer Based Learning Media of Lectora Inspire to Enhance Conceptual Skills of Senior High Schools Students
}

\author{
Wilta Fajina \\ Postgraduate Program of Chemistry Education \\ State University of Medan \\ Medan, Indonesia \\ witafajrina@gmail.com
}

\author{
Murniaty Simorangkir \\ Postgraduate Program of Chemistry Education \\ State University of Medan \\ Medan, Indonesia
}

\author{
Nurfajriani \\ Postgraduate Program of Chemistry Education \\ State University of Medan \\ Medan, Indonesia
}

\begin{abstract}
This study aimed to understand level of feasibility of learning media based-Lectora Inspire for special topic of acids and bases developed according to BSNP standard for interactive computer media; and to know the differences of the improvement of students is conceptual skills in learning acids and bases studied by using computer media of Lectora Inspire developed with power-point. It used $R \& D$ method (Development Research) with model ADDIE. The population of this study was students of class XI and teachers in MAN 2 Langsa, and lectures of Postgraduate Program of Chemistry Education at State University of Medan. Sample in this study was students of class MIA 1 and MIA 2 which have 30 students for each class. The BSNP questionnaire was used as the instrument after had been integrated with computer interactive media, and multiple choice questions used to measure students conceptual skills. Data were analyzed using descriptive method and statistical analysis with independent sample t-test. The result showed that: the developed learning media of Lectora Inspire was categorized with level of very feasible by content feasibility of $\mathbf{4 . 8}$ and presentation feasibility of 4.7, and there was the difference of students conceptual skills $(\mathrm{N}$ gain of students) for special topic of acids and bases that learned using computer media of Lectora Inspire which had been developed with power-point media $(0.041)$.
\end{abstract}

Keywords - interactive learning media; lectora inspire; conceptual skills; acids and bases

\section{INTRODUCTION}

The rapid development of science and technology has a major influence in improving the quality of teachers in Indonesia. Efforts to improve the quality of teachers can be done with innovations in learning such as the development of learning methods, provision of teaching materials, procurement of laboratory equipments, improvement of teacher quality and development of learning media [1]. Learning media which have been applied in learning is expected to streamline the learning process, to achieve the learning objectives in order to improve students learning achievement, as well as to motivate them towards the subject matter. According to Rasim and Setiawan [2], the development of learning media by utilizing Information and Communication Technology (ICT) in schools is very good choice, especially if applied in the shape of computer-based interactive media. Computer-based learning provides opportunities for students and teachers in learning to combines active learning with computer technology [3]. Collaborative learning supported by computers to study science, found a significant increase from pretest to posttest. The complexity of the material conveyed for students can be simplified by the presence of media [4]

An interview with one of the chemistry teachers of MAN 2 Langsa obtained information that the chemistry learning that occurs in this school still uses conventional methods and sometimes uses discussion methods, the use of instructional media in the school environment was still small because there were still many teachers who are limited in use of computer or laptop devices. The media used by the teacher is only a simple power point, videos from the internet, books, and Gallery walks. The teacher's interview statement was in accordance with Faruk [5] explanation of the current teaching and learning process, many still use conventional learning media such as books, modules, and powerpoint files (ppt slides without animation).

Learning process always involve teachers and students. Nurfajriani and Nasution [6] explained that the teachers should be able to stimulate and provide encouragement and reinforcement to dynamize the potential of students, activities and motivation so the teaching and learning process will be more interesting for creating a good learning achievement. Based on interview, it was also known that student learning achievement in acids and bases material was still low. The learning process of acid and base material that has been carried out in the form of group discussions and dominated by 
smart students while others students still appear to be less active due to a lack of their understanding to the learning topic. Consequently, the average learning achievement for acids and bases chemistry never gained to the minimum completeness criteria (KKM) set by the school, where the KKM for chemistry subjects is 75 .

One solution to overcome these problems is by developing interactive computer-based learning media, namely Lectora Inspire. According to Hasanah [7] Lectora Inspire is a kind of Authoring Tools which are effective in creating learning media. Lectora is used to develop digital content of teaching materials and test material in the form of multimedia dynamic, easy (user friendly) and quality without the need for art design skills and graphic design and high programming to follow the changing dynamics of teaching and learning systems, because Lectora Inspire has an interface which is familiar with we who have known or mastered microsoft office. Vectora Inspire has quite complete features, from inserting images, inserting videos, flash animation to inserting educational games. Apart from that, the uniqueness and completeness of other lectora Inspire lies in the ability to insert practice questions complete with feedback that shows right or wrong answers, and scores that can be known directly. It is easy for teachers to make an assessment because it automatically scores or scores appear [8]. The types of questions that can be made on lectora inspire also vary, there are multiple choice questions, right-wrong questions, short stuffing questions, matching / matching questions, pull and place questions, and location determination questions.

From the research conducted by Yoto [9] it is known that the use of Lectora Inspire media on the material of gas kinetic theory from the results of field tests obtained the average data of students' learning outcomes in the pretest stage was 42.0 in the low category, while the average student learning achievements in the posttest stage are 80.26 in the high category. And according to Linda [10], the response of teachers and students to the development of the Lectora Inspire media in the chemical reaction rate material was presented by the percentage of $96.67 \%$ and $97.3 \%$ while the subject matter of salt hydrolysis obtained $98.3 \%$ and $96.5 \%$. The purpose of this study was to determine the feasibility level of interactive computer based learning media of lectora inspire for special topic of acids and bases which had been developed in accordance with the BSNP standard integrated computer interactive media and to determine differences in the improvement of students' conceptual skills of acid and base material which was learned using the developed Lectora Inspire computer media with power-point media.

\section{METHODS}

This study was conducted in MAN 2 Langsa. The population for this study was students of class XI in MAN 2 Langsa. The samples were class MIA 1 and MIA 2 where both of classes were elected using technique of purposive sampling. 30 students of class MIA 1 were taught using power-point media, and 30 students of class MIA 2 using interactive learning media, namely Lactora Inspire which is had been developed (Experiment II). It was research development with a model of ADDIE (Analysis, Design, Development, Implementation and Evaluation).

\section{A. Research Instrument}

The research used methods by test and non-test as instrument. Non-test instrument that have been used was BSNP questionnaire integrated with interactive computer. While the test instrument was multiple choice questions which consisted of 20 questions concerned about acids and bases, and it was validated before it used. Questions test were arranged in accordance with Bloom Taxonomy. Data were completely collected after the answer sheets have been assessed and scored.

\section{B. Data Analysis}

There are several steps for data analysis of this study: (1) tabulating the data obtained from N-gain for students' pretest of class of experiment I and experiment II; (2) tabulating the data gained from $\mathrm{N}$-gain post-test for class of experiment I and experiment II; (3) testing for data normality; (4) testing the data homogeneity; and (5) testing the hypothesis using independent sample T-test with program SPSS 21 for Windows by significant value of 0.05 where $\mathrm{Ha}$ will be accepted and $\mathrm{H} 0$ will be rejected if $-\mathrm{t}$ count $<-t$ table or $\mathrm{t}$ count $>\mathrm{t}$ table for receiving alternative hypothesis [11].

\section{RESULTS}

This learning media was developed using model of ADDIE. It has 5 stages, namely analysis, design, development, implementation and evaluation. This study was conducted in two classes with different treatment for each class where class of experiment I was taught using Lectora Inspire and class of experiment II was taught using power point media.

\section{A. Description of Study}

The assessment for Lectora Inspire media developed by validators using BSNP questionnaire integrated with interactive computer and scale of Likert can be seen in Figure 1.

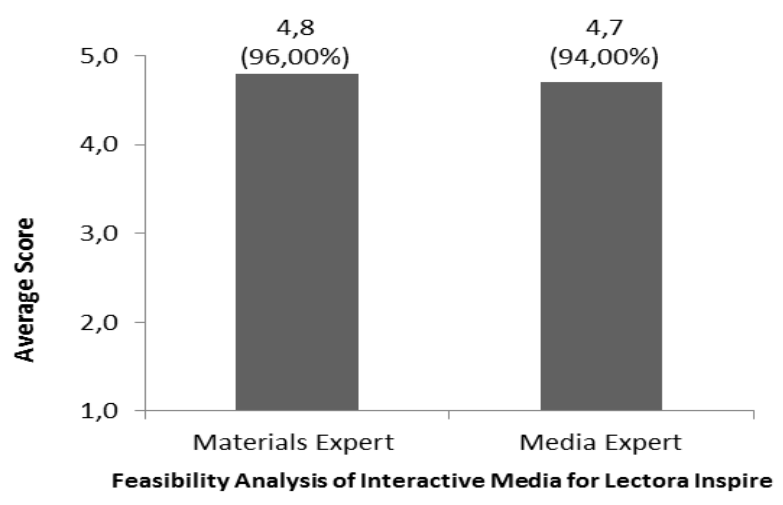

Fig 1. Avarage score for Developing Lectora Inspire Media

Then, data N-gain pretest and posttest for class experiment I and class of experiment II will be shown in Table 1. 
TABLE 1. Data of N-gain for Experiment I and Experiment II

\begin{tabular}{ccccccc}
\hline \multirow{2}{*}{ Classes } & $\begin{array}{c}\text { Number of } \\
\text { Students }\end{array}$ & \begin{tabular}{c} 
pretest \\
\cline { 3 - 5 }
\end{tabular} & $\begin{array}{c}\text { Average } \\
\text { Scores }\end{array}$ & $\begin{array}{c}\text { Average } \\
\text { Scores }\end{array}$ & N-gain & Category \\
\cline { 1 - 4 } Experiment I & 30 & 31.60 & 78.80 & 0.63 & Middle \\
Experiment II & 30 & 34.53 & 82.13 & 0.73 & High \\
\hline
\end{tabular}

\section{B. Prerequisite test for Data Analysis}

This session includes normality test and homogeneity test for pretest and posttest. Both of the prerequisite tests were done using SPSS koromogorov - Sminov, and the data told that the score of pretest and posttest for both of classes was normally distributed as good as the significant value of 0.05 . The result for normality test of $\mathrm{N}$-gain for Conceptual Skills of the sample will be shown in Table 2.

TABLE 2. Normality Analysis for N-Gain of Conceptual Skills

\begin{tabular}{ccccc}
\hline \multirow{2}{*}{ Variabels } & Classes & \multicolumn{2}{c}{ Kolmogrov- Smirnov } & \\
\cline { 3 - 4 } & & $\alpha$ & Sig.(2-tailed) & \\
\hline $\begin{array}{c}N \text {-Gain for } \\
\text { conceptual } \\
\text { skills }\end{array}$ & Experiment I & 0.05 & 0.885 & Normal \\
\hline
\end{tabular}

After that, the homogeneity test was done using Levene test in order to understand the origin of sample which are represent as homogeny data or non-homogeny data. For instant, the result of this calculation for homogeneity data of samples will be presented in Table 3 .

TABLE 3. Result of Homogeneity Test

\begin{tabular}{cccc}
\hline Data & $\alpha$ & Sig & Conclussion \\
& & & \\
\hline N-Gain for conceptual skills & 0,05 & 0,063 & Homogeny
\end{tabular}

According to Table 2 and Table 3, it can be concluded that data for this study had been qualified to be continued with hypothesis test for the research.

\section{Hypothesis Test}

This test was proposed to observe the successfulness of media in chemistry learning developed to enhance students' achievement as their conceptual skills examined using independent sample T-test. The result will be presented in Table 4.
TABLE 4. Result for Hypothesis Test

\begin{tabular}{|c|c|c|c|c|c|}
\hline Hypothesis & $\begin{array}{l}\text { Sig.(2- } \\
\text { tailed) }\end{array}$ & $\alpha$ & $-t$ count & -t table & Conclussion \\
\hline $\begin{array}{l}\text { There is a } \\
\text { difference of } \\
\text { conceptual } \\
\text { skills of } \\
\text { students who } \\
\text { learned acids } \\
\text { and bases } \\
\text { taught using } \\
\text { computer } \\
\text { media of } \\
\text { Lectora } \\
\text { Inspire }\end{array}$ & .041 & 0.05 & -2.091 & -2.001 & $\begin{array}{c}\mathrm{H}_{\mathrm{a}} 1 \text { is } \\
\text { accepted }\end{array}$ \\
\hline
\end{tabular}

Based on the result, it showed that significant value (2-tailed) is less than $0.05(0.041<0.05)$ and $(0.000<0.05)$. Then, the value of $\mathrm{t}$-count is also less than $-\mathrm{t}$ table $(-2.091<-2.001)$ and $(-5.410<-2.001)$, so according to the testing criteria as far as $\mathrm{Ha}$ will be accepted if significant value $<0.05$ and $\mathrm{H} 0$ will be simultaneously rejected if $-\mathrm{t}$ count $<-\mathrm{t}$ table [11]. Because of the value is less than 0.05 and $-\mathrm{t}$ count $<-\mathrm{t}$ table, so $\mathrm{H} 0$ will be rejected and $\mathrm{Ha}$ will be completely accepted.

\section{DISCUSSIONS}

The product produced from this developing research is a CD (Compack Disc). It is created and designed by the researchers, with the aim of being used as a tool for teachers to transfer the lesson materials and also as a source of independent learning which can be used by students outside of school at any time. This development process starts from the analysis step by conducting necessary analysis, literature analysis, and previous media analysis that was once available or used in MAN 2 Langsa. The next step design, the learning media developed using the Lectora Inspire software / software application. This step begins with making a flowchart and storyboard. Then the assessment process is carried out by an expert validator to find out whether the product is valid or not. The aspects assessed are content eligibility (Expert Materials) consisting of aspects of learning, aspects of teaching materials and aspects of language. Feasibility of presentation (Media Expert) consists of aspects of media design / appearance, aspects of audio / visual display and aspects of media operations. Based on the results of the study, the developed lectora inspire learning media products are of good quality to be tested with $96.00 \%$ material aspects and $94.00 \%$ media aspects.

Based on the results of the study on differences in the enhancement of students' conceptual skills in learning of acids and bases using the Lectora Inspire computer media developed with power point media. It can be seen from the average value of the posttest $\mathrm{N}$-gain and the student's pretest where the experiment II class is 0.73 higher than the experimental class 
$\mathrm{I}$, which is 0.63 . So that in testing the independent sample ttest the data shows sig. (2-tailed) $0.041<0.05$ and -t count ($2.092)<-$ t table $(-2.001)$ then based on the criteria $\mathrm{H} 0$ is rejected and $\mathrm{Ha}$ is accepted, so there is a difference in the improvement of students' conceptual skills on special topic of acids and bases using Lectora Inspire's computer media taught with power point media. Increased of the conceptual skills of $\mathrm{N}$-gain students using this lectora inspire media is also supported by research presented by Wibawa [12], the average percentage of responses to student learning achievement is $84.375 \%$. Based on this data it can be concluded that the media lectora obtain good results and it can be effective as a learning tool to support the students' learning activities. Lectora inspire has several advantages over other e-learning authoring tools, namely: (1) Lectora is easy, can be used by teachers or anyone who has not (or not) is adept at using complicated programming materials; (2) Lectora is multifunctional, can be used to create websites, interactive elearning content, and product presentations or company profiles; (3) The features provided by Lectore Inspire greatly facilitate novice users to create multimedia (audio and video) learning; (4) Lectora template is quite complete; (5) Lectora Inspire provides a media library that is very helpful to users; (6) Lectora allows users to convert Microsoft Power Point presentations to e-learning content; And (7) Lectora Inspire provides 8 types of questions which are easy to apply with a score at the end of the evaluation [13].

\section{CONCLUSION}

Based on data analysis and discussion of the results of the research conducted, the conclusions can be drawn as follows: (1) The developed Lectora Inspire learning media has a very feasible category so it is suitable for use in chemistry learning. (2) There is a difference in the enhancement of conceptual skills (N-gain) of students for special topic of acids and bases using Lectora Inspire computer media which has been developed with power point media obtained significant data that is $0.041<0.05$.

\section{Acknowledgment}

Praise is merely to the Almighty Allah SWT for His gracious mercy and His tremendous blessing in doing this research. The gratitude is expressed to Murniaty Simorangkir and Nurfajriani who has given an instruction and opportunity to conduct the research, and the students who involved in the research through my theses.

\section{References}

[1] O. Hamalik, "Teaching and learning process", Jakarta, Sinar Grafika, 2007.

[2] Rasim and W. Setiawan, "Development of Instructional Devices for Information Technology and Technology-Based Learning", Jurnal Pendidikan TIK, vol 1(2), pp. 1-10, 2008

[3] H. Akcay, A. Durmaz, C. Tüysüz, and B. Feyzioglu, "Effects of computer based learning on students' attitudes and achievements towards analytical chemistry". TOJET, The Turkish Online Journal of Educational Technology, vol 5(1), pp. 44-48, 2006
[4] M.S Zuhri, and E.A Rizaleni, "Development of Lectora Inspire with Contextual Approach to Class X Senior High School",. PYTHAGORAS, vol 5(2), pp. 113- 119, 2017.

[5] A.Faruk, "Development of Interactive Learning Media Based Lectora Inspire in Discrete Method Course. Proceeding of Internasional Conference on Research, Implimentation and Education of Mathematich And Sciences". Yogyakarta State University. 18-20 Mei 2014.

[6] Nurfajriani and Z Nasution, "The Effect of Macromedia Flash Software on Learning with Cooperative Models of Team Assisted Individualization Type Towards Students' Chemistry Learning Outcomes in the Base of Thermochemical Material", Jurnal Pendidikan Kimia, vol 7(3), pp. 18-24, 2015.

[7] N. Hasanah, R.U Rery and S. Haryati, "Development of Learning Media Based on Lectora Inspire on the Subjects of Atomic Structure and the Periodic System of Elements for Class X SMA / MA", Jurnal Online Mahasiswa (JOM) Bidang Keguruan dan Ilmu Pendidikan, 3(1), pp. 1-9, 2016.

[8] N.D Shalikhah, A. Primadewi, and M.S Iman, "Interactive learning media lectora inspire as learning motivation”, WARTA LPM, vol 20(1), pp. 9-16, 2017.

[9] Y. Yoto, Zulkarnain, and K. Wiyono, "Development of Interactive Multimedia Learning the Kinetic Theory of Lectora Inspire Assisted Gas for High School Students (SMA)", Jurnal Inovasi Dan Pembelajaran Fisika, vol 2(2), pp.211-219, 2015.

[10] R Linda, Erviyenni, A.M. Noer, N.A. Oktavianti, and N Sellyna, "Development of Lectora Inspire as Interactive Multimedia Chemistry Learning in Senior High School”, Jurnal Pendidikan Kimia, vol 8(3), pp. 188-196,2016

[11] D. Priyanto, "Understand Data Statistical Analysis with SPSS", Yogyakarta: Mediakom, 2010

[12] S.C Wibawa, R. Harimurti, Y Anistyasari, and M.S. Sumbawati, "The Design And Implementation Of An Educational Multimedia Interactive Operation System Using Lectora Inspire", Elinvo (Electronics, Informatics, and Vocational Education), vol 2(1), pp. 74-79, 2017.

[13] M. Mas'ud, "Lectora Tutorial 1 Making Multimedia Learning With Lectora Inspire". Yogyakarta, Pustaka Shonif, 2014. 